\title{
Aeolian processes records within last glacial limit areas based on the Płock Basin case (Central Poland)
}

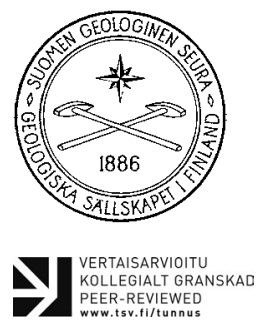

\author{
Joanna Rychel ${ }^{{ }^{*}}$, Barbara Woronko², MirosŁaW BŁaszKiewicz ${ }^{3}$ \\ AND TOMASZ KarasiewiCZ ${ }^{4}$ \\ ${ }^{1}$ Polish Geological Institute and National Research Institute, Rakowiecka 4, \\ 00-975 Warsaw, Poland \\ ${ }^{2}$ Faculty of Geology, University of Warsaw, Żwirki i Wigury 93, 02-089 Warsaw, Poland \\ ${ }^{3}$ Department of Environmental Resources and Geohazards, Institute of Geography and \\ Spatial Organization Polish Academy of Sciences, Kopernika 19, 87-100 Torun, Poland \\ ${ }^{4}$ Faculty of Earth Sciences, Nicolaus Copernicus University in Torun, Lwowska 1, \\ 87-100 Toruń, Poland
}

\begin{abstract}
Formation of dunes in the Płock Basin of the Vistula River valley in Central Poland is connected with the aeolian processes that occurred within the European Sand Belt during the Late Pleistocene. Changes in sedimentation conditions, from fluvial (unit G1), to fluvio-aeolian (unit G2) then to aeolian (unit G3), were respectively recorded in the fluvioglacial terrace sand dune profiles in the village of Goreń Duży (the Płock Basin, Central Poland). Both fluvial and aeolian processes occurred in the periglacial zone of the last glaciation, the northern limit of which is defined by the Last Glacial Maximum (LGM), being 18.4 ka in the Płock Basin. River and ice-marginal valley terrace sand sediments, in association with glacial deposits, could be the source material for the studied aeolian bedforms. The results of morphoscopic analysis of dunal sand quartz grains indicate that rapid deposition occurred more often than did long-term longrange grain transport. Grain transport genesis begins during the Older Dryas, which is confirmed by optically stimulated luminescence (OSL) dating performed for unit G2: $13.06 \pm 0.76 \mathrm{ka}$ and $13.54 \pm 0.84 \mathrm{ka}$. During dune formation, dead-ice blocks remained intact in a subglacial channel until the Allerød, which suggests that aeolian processes continued after block melting, throughout the Younger Dryas. Successional aeolian processes have resulted in the extensive dune fields of the Płock Basin.
\end{abstract}

Keywords: Aeolian, palaeo-environments, fluvio-aeolian succession; quartz grain morphoscopy, Late Pleistocene, OSL dating

*Corresponding author (e-mail: joanna.rychel@pgi.gov.pl)

Editorial handling: Pertti Sarala (pertti.sarala@gtk.fi) 


\section{Introduction}

Aeolian processes occurring during the Late Pleistocene have been extensively described in Europe (Dylikowa, 1967, 1968; Nowczyk, 1986; Zeeberg 1998; Kasse, 2002; Seppälä, 2003; van Huissteden et al., 2001; Koster 2005; Goździk, 2007; Kasse et al., 2007; Bateman, 2008; KalińskaNartiša et al., 2016; Woronko et al., 2015; Zieliński et al., 2016). Their effects, aeolian deposits and landforms, wrought elemental features of the north-central European landscape, forming the socalled European Sand Belt that stretches from Great Britain in the west, through Germany and Poland, and spans to Russia and Ukraine in the east (Koster, 1988; Zeeberg, 1998). The aeolian processes were associated with the periglacial conditions (i.e., cold, dry, windy) in the marginal zone of the last Scandinavian Ice Sheet (SIS) (Zieliński et al., 2011) and in areas located in the borderlands of the Last Glacial Maximum (Zieliński et al., 2011, 2015).

When investigating intensity of aeolian processes in Europe, Cailleux (1942) specifically focused on the fraction of highly rounded and completely frosted sand quartz grains with a diameter of 0.4$0.1 \mathrm{~mm}$, described by the author as rounded matt (RM). Very well-rounded and matt surface results from long-lasting and intensive abrasion during the movement (transportation) of grains in the process of saltation in the aeolian environment (Mycielska-Dowgiałło \& Woronko, 1998; MycielskaDowgiałło, 2001; Goździk, 2007). Cailleux (1942) registered the highest frequency of wind-modified sand grains (RM) in Central Poland. However, the concentration of RM grains in aeolian deposits in Poland varies both in N-S (Goździk, 1998; Zieliński et al., 2015) and W-E directions (Zieliński et al., 2016). In this case, an ice-sheet positional factor had a major and direct impact on the duration of aeolian processes, which resulted in the division of the area of aeolian process development into an ice-free extraglacial zone, occupying the LGM foreland, and newly exposed areas released from under ice cover. An equally important factor driving these aeolian processes was climate in particular the degree of continentality (Mycielska-Dowgiałło \& Woronko, 2004; Zieliński et al., 2016). Based on distribution of dune fields and coversand accumulation during the last Pleistocene glaciation, Zeeberg (1998) distinguishes three types of European aeolian environments: 1) a periglacial zone during the maximum Weichselian ice extent at its foreland from $29 \mathrm{ka}$ to $22.5 \mathrm{ka} ; 2$ ) an intermediate zone during the ice retreat from $18 \mathrm{ka}$ to $13 \mathrm{ka}$;) deglaciation zone where aeolian processes developed after the icesheet retreat between $13 \mathrm{ka}$ to $9 \mathrm{ka}$. Conditions that would typically facilitate the development of aeolian processes were instead hampered within the second and third zones listed above. Wind action in the latter zones was limited, due to the short timeframe that conditions were favourable for the development of aeolian processes. Aeolian activity was further impeded by the progressive expansion of vegetation into ice-free areas. According to Zeeberg (1998), an example of an area that may represent Zeeberg's second aeolian environment is the Płock Basin located at a midpoint in E-W bounds of the European Sand Belt (Fig. 1a).

The Płock Basin is a vast extension of the Vistula River valley, being the easternmost part of the Toruń-Eberswalde ice-marginal valley (Galon \& Roszkówna, 1961; Kozarski, 1965; Skompski, 1969; Pisarska-Jamroży, 2015). The Płock Basin's origin is related to a paleo-ice stream $\left(\mathrm{B}_{3}\right)$, a branch of the Baltic paleo-ice stream (Punkari, 1997). The maximum range of this ice-sheet occurred during the Poznań phase (LGM) in the Vistula Lobe in the Vistula River valley (Roman, 2010; Wysota \& Molewski, 2011; Tylman et al., 2017), which took place approximately $18.4 \mathrm{ka}$ according to optically stimulated luminescence (OSL) and thermalluminescent (TL) dating (Wysota et al., 2009). The retreat rate of the ice-sheet margin in the Vistula Lobe was about $450 \mathrm{~m} / \mathrm{a}$ (Wysota et al., 2009). The presence of this paleo-ice stream in the Płock Basin is connected with the system of NW-SE and N-S subglacial channels being parallel to the longer axis of this basin (Lencewicz, 1927). One of the 


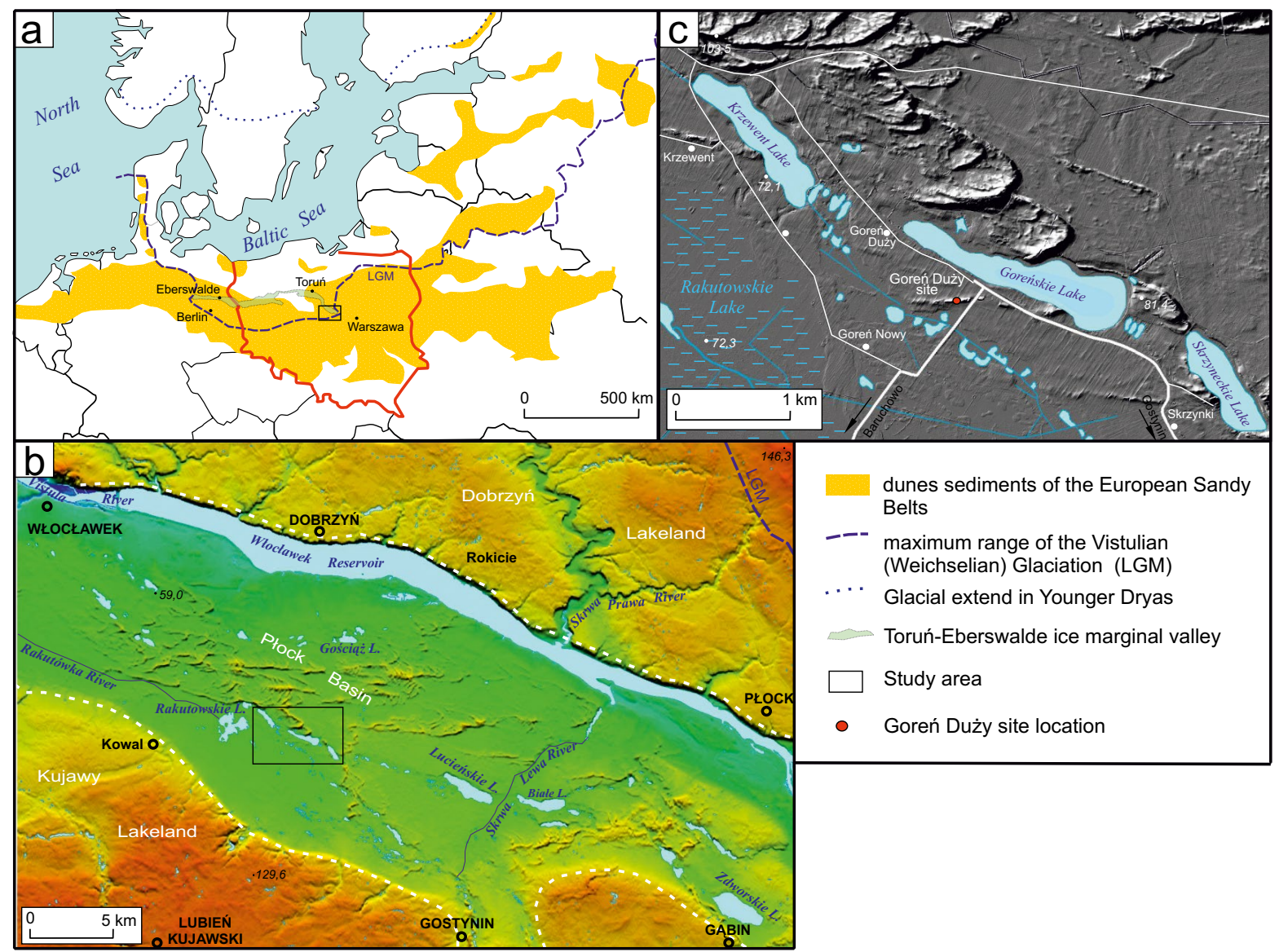

Figure 1. Location of the study area: a) Study area in the European Sand Belt; b) Płock Basin within the maximum range of the Vistulian Glaciation (LGM) (Roman, 2010); and c) Goreń Duży site.

largest subglacial channels in the Płock Basin is Lake Goreńskie with a length of $2 \mathrm{~km}$. According to palynological and ${ }^{14} \mathrm{C}$ data, the valley bottoms were preserved by dead ice that melted mainly in the Allerød (Ralska-Jasiewiczowa et al., 1998), which had a major effect on aeolian processes in this region (Urbaniak-Biernacka, 1976). This dead-ice melting was connected with permafrost degradation during climate amelioration.

The objective of this study was to: 1) to reconstruct the intensity of aeolian processes in the Płock Basin based on Goreń Duży dune structure and textural features deposit grain size distribution and morphoscopy of its sand quartz grains, 2) compare the activity of aeolian processes developing in the SIS foreland to the area exposed after the ice-sheet margin retreat in the Vistula Lobe as related to its position in the European Sand Belt (Fig. 1b), and 3) determine the relation between aeolian landforms and associated negative landforms composed in glacial relief, e.g., subglacial channels as viewed in LiDAR imagery.

\section{Study area and geological setting}

The Płock Basin is about $18-20 \mathrm{~km}$ wide and has a broad left-bank fluvial terrace of sand. There are numerous postglacial lakes and dunes and a floodplain now substantially inundated as a result of a retention reservoir built here in the late 1960s. 
Dunes in the Płock Basin form a belt with a length of about $50 \mathrm{~km}$ and a width ranging from $10 \mathrm{~km}$ in the west to about $18 \mathrm{~km}$ in the east (Urbaniak, 1967) along with a few other smaller dune fields outside this belt. The relative height of individual dunes reaches $35 \mathrm{~m}$. The highest one is a ridge called Patrolowa Góra that has a height of $114.6 \mathrm{~m}$ a.s.l.. Aeolian forms are represented by parabolic, longitudinal and irregular dunes (Fig. 1b).

The studied dune in Goreń Duży (52³1'39” N; $19^{\circ} 17^{\prime} 45^{\prime \prime} \mathrm{E}$ ) is located about $180 \mathrm{~m}$ south of Lake Goreńskie, the shoreline of which runs at an angle of about $30^{\circ}$ in relation to the dune crest (Fig. 1c). It is a narrow longitudinal W-E dune, with a length of approximately $1 \mathrm{~km}$ and a relative height of up to $8 \mathrm{~m}$. It is located on the ice-marginal terrace (Skompski, 1969) between a large kettle hole of Lake Rakutowskie in the south and a subglacial channel represented by Lake Goreńskie, Lake Krzewent and Lake Skrzyneckie in the north (Urbaniak, 1962; Urbaniak-Biernacka, 1976; Rychel et al., 2015). Urbaniak (1967) suggested that only distal slopes of dunes were preserved in the Płock Basin. She reported that the dune accumulation from the northern side of Lake Goreńskie was a result of wind blowing from the southern sector. Dunes in the Płock Basin are the dominant element of relief; being very well developed and they cover large areas. Therefore, the regional government legally protected the dune field as part of the Gostynin-Włocławek Landscape Park created in 1986.

\section{Materials and Methods}

Research on the dune in Goreń Duży was carried out in two stages. The first stage included a description of the structural and textural features of the dune deposits along an outcrop wall with a profile height of $10 \mathrm{~m}$ revealing dune sediments and their substratum. A detailed structural analysis was performed using a lithofacies code, as proposed by Zieliński \& Pisarska-Jamroży (2012). Measurements were then taken of directional structures. Additionally, 27 samples were collected for further laboratory analysis. In the second stage of research, the textural features of the sediments were analysed and grain size distribution, morphoscopy of quartz grains and loss on ignition were measured. Grain size analysis was performed using sieve and laser methods dry sieve analysis using a set of sieves for the fractions ranging from 2.0 to $0.1 \mathrm{~mm}$ and Fritsch Laser Particle Sizer Analysette 22 for the fractions below $0.1 \mathrm{~mm}$. Statistical indices of grain size composition were calculated according to Folk \& Ward (1957): average grain diameter (Mz), standard deviation $\left(\sigma_{\mathrm{I}}\right)$ as a measure of sediment sorting, and skewness $\left(\mathrm{Sk}_{\mathrm{r}}\right)$ showing the asymmetry of sediment distribution. For the statistical analysis, the software GRADISTAT_5_11_PL_beta was used (Blott \& Pye, 2001).

Morphoscopic analysis of quartz grains was performed for $0.5-0.8 \mathrm{~mm}$ and $0.8-1.0 \mathrm{~mm}$ fractions according to the method as proposed by Cailleux (1942) and modified by MycielskaDowgiałło \& Woronko (1998). This analysis provides information on the genesis of sediments, duration of aeolian processes, dune sediment source areas (alimentary areas), the degree of sediment transformation as well as all post-depositional processes (Mycielska-Dowgiałło \& Woronko, 1998). Seven types of quartz grains were distinguished according to the last process marked on the surface of quartz grains (Table 1). In each instance, 100 to 150 randomly selected grains were analysed (after being etched in $10 \mathrm{M} \mathrm{HCl}$, then washed with distilled water).

The organic matter content (OM) was determined based on the weight loss after dry sediment samples were heated at $550^{\circ} \mathrm{C}$ for 3 hours.

In order to establish the time when aeolian processes began, two samples of sandy sediments were collected to determine their age using OSL, which indicates the time that has elapsed since the last exposure of sediments to daylight (Aitken, 1998). Dating was conducted in the Centre of Excellence GADAM at the Institute of Physics, Silesian University of Technology, in accordance with the procedures applied there (Moska, 2017; 
Table 1. Type of roundness and frosting of quartz sand grains (0.8-1.0 mm) according to Cailleux (1942) as modified by MycielskaDowgiało \& Woronko (1998).

\begin{tabular}{|c|c|l|l|}
\hline $\begin{array}{c}\text { Class of } \\
\text { grain }\end{array}$ & $\begin{array}{c}\text { Roundness } \\
\text { of grain acc. } \\
\text { to Krumbein } \\
(1941)\end{array}$ & \multicolumn{1}{|c|}{ Description } & \multicolumn{1}{|c|}{ Processes responsible for the formation of grain } \\
\hline RM & $0.7-0.9$ & $\begin{array}{l}\text { Very well rounded with } \\
\text { complitly mat surface }\end{array}$ & Very long duration abrasion in aeolian environment \\
\hline EM/RM & $0.3-0.6$ & $\begin{array}{l}\text { Moderately rounded, mat surface } \\
\text { only on convexed parts of grains }\end{array}$ & $\begin{array}{l}\text { Short time duration abrasion in aeolian environment } \\
\text { marked only on convexed parts of grains }\end{array}$ \\
\hline EL & $0.7-0.9$ & $\begin{array}{l}\text { Very well rounded with smooth, } \\
\text { shiny the entire surface }\end{array}$ & $\begin{array}{l}\text { Combination of abrasion and solution in fluvial or beach } \\
\text { environment. Very well roundness of grains indicates long } \\
\text { duration of processes }\end{array}$ \\
\hline EM/EL & $0.3-0.6$ & $\begin{array}{l}\text { Moderately rounded, smooth } \\
\text { and shiny surface }\end{array}$ & $\begin{array}{l}\text { Combination of abrasion and solution in fluvial or beach } \\
\text { environment }\end{array}$ \\
\hline C & - & Crushed/Broken & $\begin{array}{l}\text { Crushing in all type of environments but the most intensive in } \\
\text { subglacial environment or as an effect of frost weathering }\end{array}$ \\
\hline NU & $0.1-0.2$ & $\begin{array}{l}\text { All surface are fresh, corners are } \\
\text { sharp and angular }\end{array}$ & $\begin{array}{l}\text { Crushing and abrasion in glacial environment; } \\
\text { mechanical weathering in situ e.g. frost weathering }\end{array}$ \\
\hline O & $0.1-0.9$ & $\begin{array}{l}\text { In situ very intensive weathered } \\
\text { surface by silica precipitation or } \\
\text { solution; No visible transport trails }\end{array}$ & $\begin{array}{l}\text { Solution or precipitation in soil profile, hot desert } \\
\text { environment or periglacial environment }\end{array}$ \\
\hline
\end{tabular}

Table 2). A total of 12 aliquots were conducted for a sample collected at a depth of $8.75 \mathrm{~m}$ and 13 aliquots for a sample collected at a depth of $8.1 \mathrm{~m}$. The averaged result is herein provided (Galbraith et al., 1999). Measurements were made using Daybreak 2200 and Risø luminescence readers. The irradiation was performer using a calibrated ${ }^{90} \mathrm{Sr} /{ }^{90} \mathrm{Y}$ beta source with a power of $3.0 \mathrm{~Gy} / \mathrm{min}$. The absorbed dose was determined by the Single Aliquot Regenerative (SAR) method (Murray \& Roberts, 1998). The final absorbed dose was determined using the Central Age Model (CAM) (Galbraith et al., 1999).

\section{Results}

\subsection{Sedimentary structures and age}

Based on the structural analysis of sediments at the Goreń Duży site, sediments exposed in the outcrop were divided into three units G1, G2 and G3 with erosional boundaries in between (Fig. 2).

Sediments of unit G1 lie at a depth below $9.6 \mathrm{~m}$. The uppermost (top) layers of this unit are built of cross-bedded sands (Sp) (Fig. 2).
Sediments of unit G2, with a thickness of $1.95 \mathrm{~m}$, lie at a depth of 7.65-9.60 m. Fine- and medium-grained horizontally stratified sand (Sh) and trough cross-stratified sand $(\mathrm{St})$ occur in the uppermost and bottom layers (Fig. 2). The middle part of unit G2 is built of horizontally stratified sand $(\mathrm{Sh})$, massive structure $(\mathrm{Sm})$ and silty sand with wavy lamination $(\mathrm{SFw})$, forming the rhythmite Sh->SFw (Fig. 2a). Accessory lithofacies in the sediments of this unit are represented by massive sand (Se) and massive gravelly sand (SGe), filling a shallow erosional scour with a depth of up to $0.35 \mathrm{~m}$ and a varying width, which ranges from $0.10 \mathrm{~m}$ to over $0.5 \mathrm{~m}$. At least 5 levels of small-scale involutions were found in the sediments of unit G2, developed at the contact zone of horizontally stratified sandy deposits (Sh), and sand with massive structure $(\mathrm{Sm})$ in the top layer and in the rhythmite Sh->SFw (Fig. 2a). The orientation of the current elements in sediments of unit G2 varied from NNE to SSE at the bottom, to NNW in the central part and at the top (Fig. 2). According to the OSL method, deposits of this unit are dated at: $13.06 \pm 0.76 \mathrm{ka}$ (GdTL-2695) and $13.54 \pm 0.84 \mathrm{ka}$ (GdTL-2696) (Figs 2, 3; Table 2). 


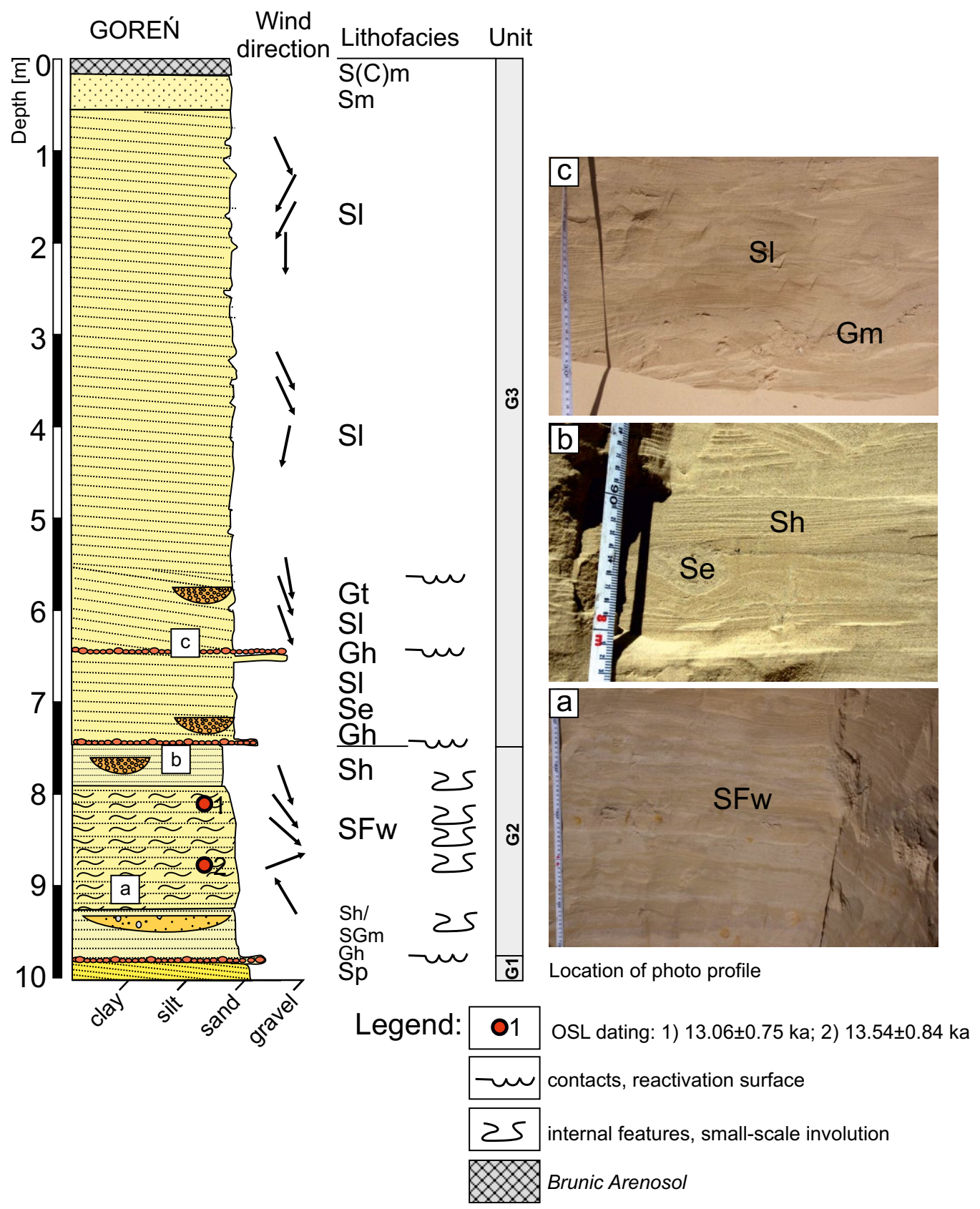

Figure 2. Sedimentological log of deposits in the Goreń Duży profile at Goreń Duży site: a) silty sand with wavy lamination (SFw) with four generations of small-scale involution structures; b) fine- and medium-grained horizontally stratified sand (Sh) with a small-scale erosion trough filled with trough cross-stratified sand (Se); c) low-angle $\left(<15^{\circ}\right)$, cross-stratified fine sand (SI) overlaying fine-grained gravel horizone $(\mathrm{Gm})$ along with the reactivation surface. 
Table 2. Sample information, dosimetry and luminescence age. The quartz grainfraction wer 125-200 $\mu$ m. Depths are given in metres below the outcrop top. Water content (WC) was calculated as mass of water/mass of dry sediment $x 100 \%$. Dose rates were calculated following geochemical analysis of $\mathrm{U}$, Th and K concentrations for each sample, using the conversion factors of Adamiec \& Aitken (1998).

\begin{tabular}{|c|c|c|c|c|c|c|c|c|c|c|c|c|c|}
\hline $\begin{array}{l}\text { Field } \\
\text { code }\end{array}$ & $\begin{array}{l}\text { Laboratory } \\
\text { code }\end{array}$ & $\begin{array}{c}\text { Sample } \\
\text { coordinates }\end{array}$ & $\begin{array}{c}\text { Depth } \\
(\mathrm{m})\end{array}$ & $\begin{array}{l}\text { WC } \\
(\%)\end{array}$ & $\begin{array}{c}{ }^{232} \mathrm{Th}^{-1} \\
\left(\mathrm{~Bq} \mathrm{~kg}^{-1}\right)\end{array}$ & $\begin{array}{c}{ }^{238} \mathrm{U} \\
\left(\mathrm{Bq} \mathrm{kg}^{-1}\right)\end{array}$ & $\mid \begin{array}{c}{ }^{40} \mathrm{~K}^{-1} \\
\left(\mathrm{~Bq} \mathrm{~kg}^{-1}\right)\end{array}$ & $\begin{array}{c}\beta \text { dose rate } \\
\left(\text { Gy kg }{ }^{-1}\right)\end{array}$ & $\begin{array}{c}\text { ydose rate } \\
\left(\text { Gy kg }{ }^{-1}\right)\end{array}$ & $\begin{array}{c}\text { Cosmic } \\
\text { dose rate } \\
\left(\text { Gy kg }^{-1}\right)\end{array}$ & $\begin{array}{c}\text { Total } \\
\text { dose rate } \\
\left(\text { Gy kg }^{-1}\right)\end{array}$ & $\begin{array}{l}\mathrm{D}_{\mathrm{e}} \\
\text { (Gy) }\end{array}$ & Age \\
\hline $\begin{array}{l}\text { Goreń } \\
\text { Duży_1_15 }\end{array}$ & GdTL-2695 & $\begin{array}{l}52^{\circ} 31^{\prime} 39^{\prime \prime} \mathrm{N} \\
19^{\circ} 17^{\prime} 45^{\prime \prime} \mathrm{E}\end{array}$ & 8.1 & 1.5 & $10.75 \pm 0.49$ & $10.84 \pm 0.29$ & $413 \pm 19$ & $0.951 \pm 0.066$ & $0.462 \pm 0.020$ & $0.0208 \pm 0.0021$ & $1.438 \pm 0.069$ & $18.87 \pm 0.61$ & $13.06 \pm 0.76$ \\
\hline $\begin{array}{l}\text { Goreń } \\
\text { Duży_2_15 }\end{array}$ & GdTL-2696 & $\begin{array}{l}52^{\circ} 31^{\prime} 39^{\prime \prime} \mathrm{N} \\
19^{\circ} 17^{\prime} 45^{\prime \prime} \mathrm{E}\end{array}$ & 8.75 & 6.7 & $10.12 \pm 0.49$ & $10.09 \pm 0.33$ & $415 \pm 19$ & $0.947 \pm 0.067$ & $0.452 \pm 0.020$ & $0.0193 \pm 0.0019$ & $1.422 \pm 0.070$ & $19.35 \pm 0.71$ & $13.54 \pm 0.84$ \\
\hline
\end{tabular}
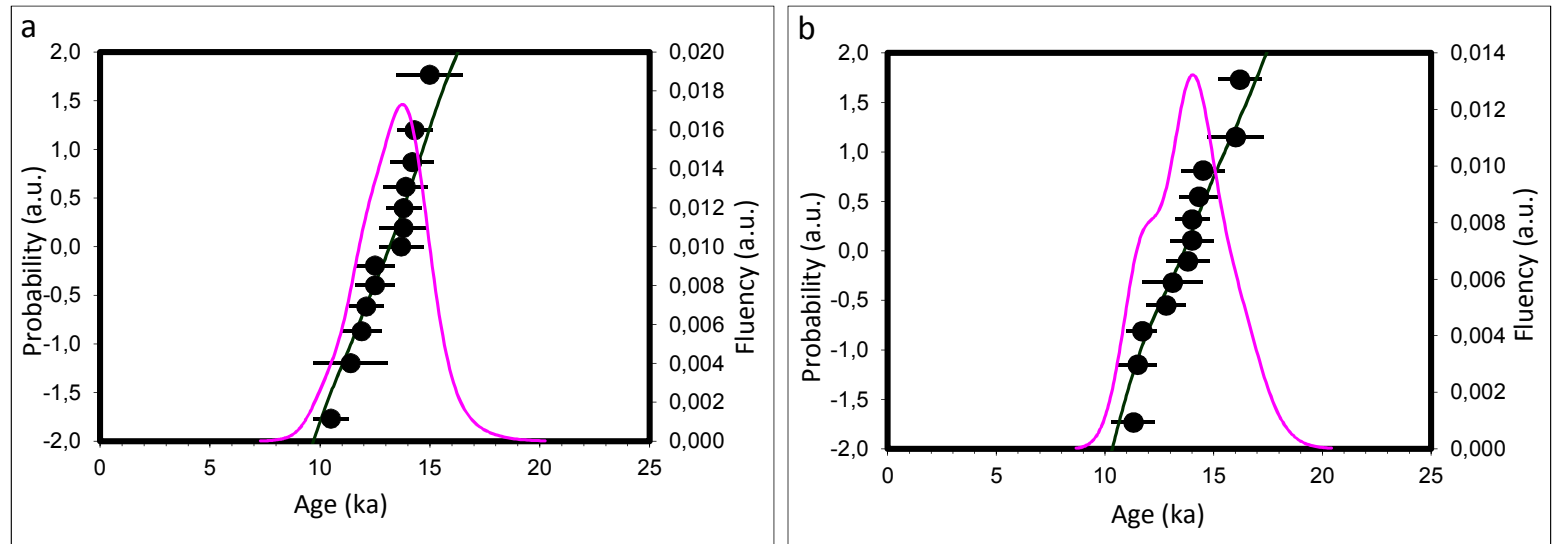

Figure 3. CAM for samples: a - Goreń Duży_1_15 (GdTL-2695); b - Goreń Duży_1_15 (GdTL-2696).

Unit G3 is represented by low-angle $\left(<15^{\circ}\right)$, cross-stratified fine sand $(\mathrm{Sl})$ with a thickness of about $7.65 \mathrm{~m}$ (depth $0.0-7.65 \mathrm{~m}$ ) and an inclination of up to $10^{\circ}$. Small-scale trough crossstratified sands (Se) occur in the bottom layer of the unit, filling small erosional forms (Fig. 2b), along with the reactivation surface that is characterised by the presence of fine-grained gravel with a thickness of 2-3 $\mathrm{mm}$ and change of laminae inclination (Fig. 2c). Brunic Arenosol developed in the uppermost part of the deposits at this site. Boundaries between the unit G3 and G2 series are eroded. The orientation of the wind direction slightly varies over the unit, from NNE to NNW (Fig. 2).

\subsection{Textural features of the deposits}

G1 unit deposits have not been analysed in terms of grain size composition.

Medium-grained sand $(0.1-0.25 \mathrm{~mm})$ dominates in the whole G2 unit (depth 7.95-9.60 m).
Their content gradually increases towards the top, ranging $33.9-55.3 \%$ in the bottom, and 70 $83.05 \%$ in the top. The content of the clay fraction $(<0.063 \mathrm{~mm})$ in the sediment is only $0.8 \%$ and the content of the gravel fraction is correspondingly low (Fig. 4). G2 unit sediments are characterised by the average grain diameter $(\mathrm{Mz})$, ranging from 1.96 to $2.76 \mathrm{phi}$, moderately well sorting-with values between $\sigma_{\mathrm{I}}=0.60$ and $\sigma_{\mathrm{I}}=0.93$ and the range of skewness $\left(\mathrm{Sk}_{\mathrm{I}}\right)$ from strongly fine skewed $(+0.356)$ to coarse skewed (-0.174) (Fig. 4). The content of organic matter is very low and ranges from 0.12 $0.21 \%$ (Fig. 4).

Sediments of G3 unit are fine-grained sand with the main fraction ranging from $0.25-0.1 \mathrm{~mm}$ and accounting for $79 \%$ at the bottom and up to $89.2 \%$ in the middle part and $86 \%$ in the uppermost layer. In addition, basic parameters of the grain size composition $\mathrm{Mz}, \sigma_{\mathrm{I}}$ and $\mathrm{Sk}_{\mathrm{I}}$ only slightly varies along the vertical profile. $\mathrm{Mz}$ is in the range of 2.67$2.72 \mathrm{phi}$. This is a well-sorted sediment (0.54-0.65) 


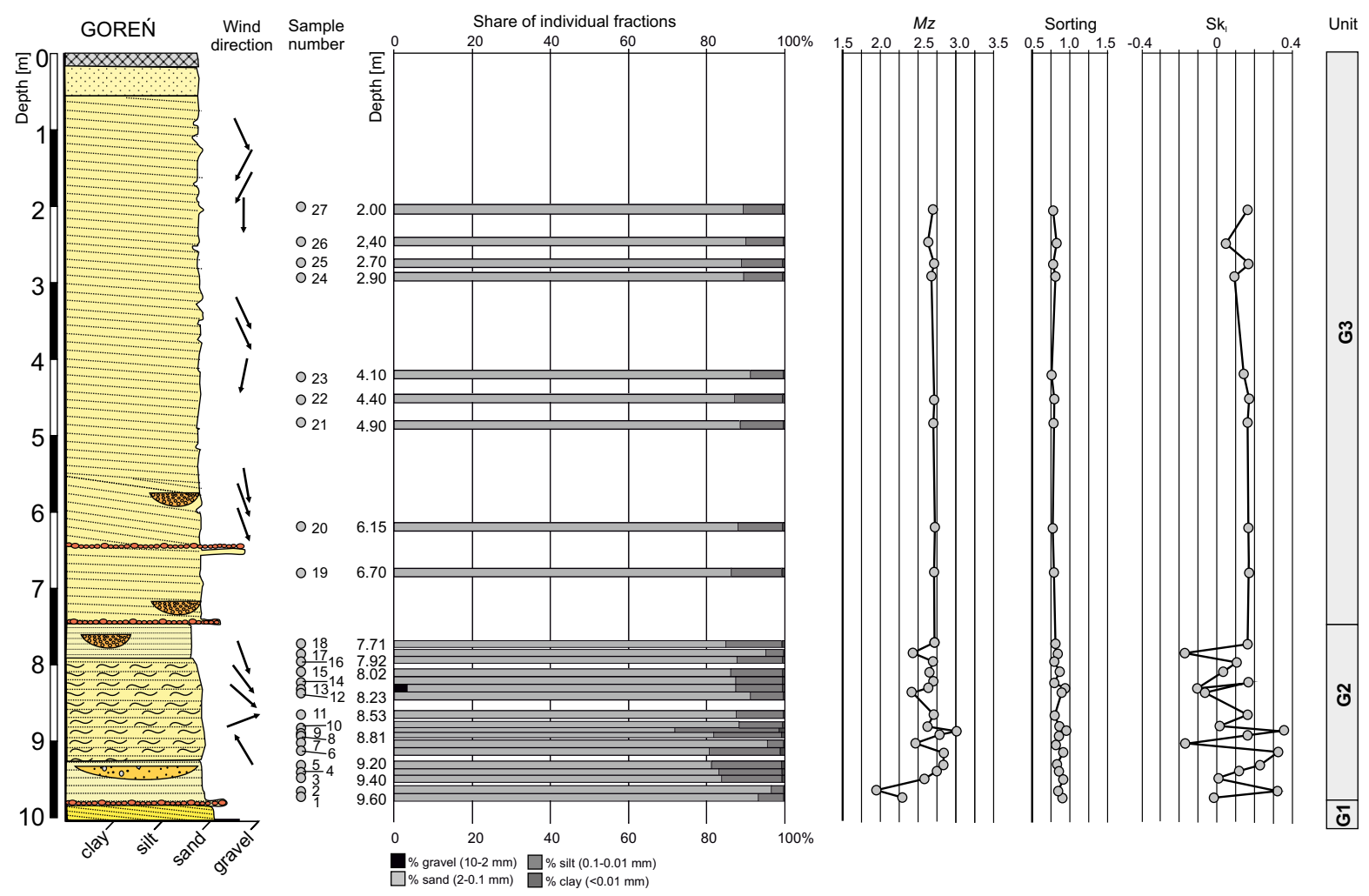

Figure 4. Results of grain-size distribution and OM analyses in the Goreń Duży profile: parameters of the grain size distribution after Folk \& Ward (1957): mean grain size (Mz), sorting or dispersion coefficient (Io), skewness (Sk).

with positive skewness (Fig. 4). These sands basically do not contain organic matter OM $(0.16-0.2 \%)$ (Fig. 4).

\subsection{Morphoscopy of quartz sand grains}

The results of Cailleux's (1942) analysis, later modified by Mycielska-Dowgiałło \& Woronko (1998), show that the deposits of unit G2 are dominated by EM/RM grains with the roundness of 0.3-0.6 according to Krumbein (1941) and only matt edges and corners, resulting from ongoing abrasion in an aeolian environment. Their content varies from 38.6-75\%. The content of EM/EL grains representing the fluvial environment is also high (from < 20-49.5\%). Conversely, RM grains with a very high degree of roundness $(>0.7$ according to Krumbein (1941) and completely matt surface were found in only one sample; their content being below $4 \%$. Also EL grains were found; being characterised by a high degree of roundness and smooth, glossy surface (from $0.9 \%$ at the bottom to $5 \%$ in the top). Grains with the surface shaped by progressive in situ weathering (type $\mathrm{O}$ ) account for less than $4 \%$ and are not recorded in the sediments (Fig. 5).

The G3 unit is dominated by two types of grains, EM/RM and EM/EL, each type with a different content in the profile. EM/RM grains account for $14.4-76.3 \%$ and EM/EL grains for $16.2-76.4 \%$ (Fig. 5); no RM grains were found. Grains with weathered surface (type O) and cracked grains (C) were also present. The content of the latter did not exceed $2 \%$ (Fig. 5). 


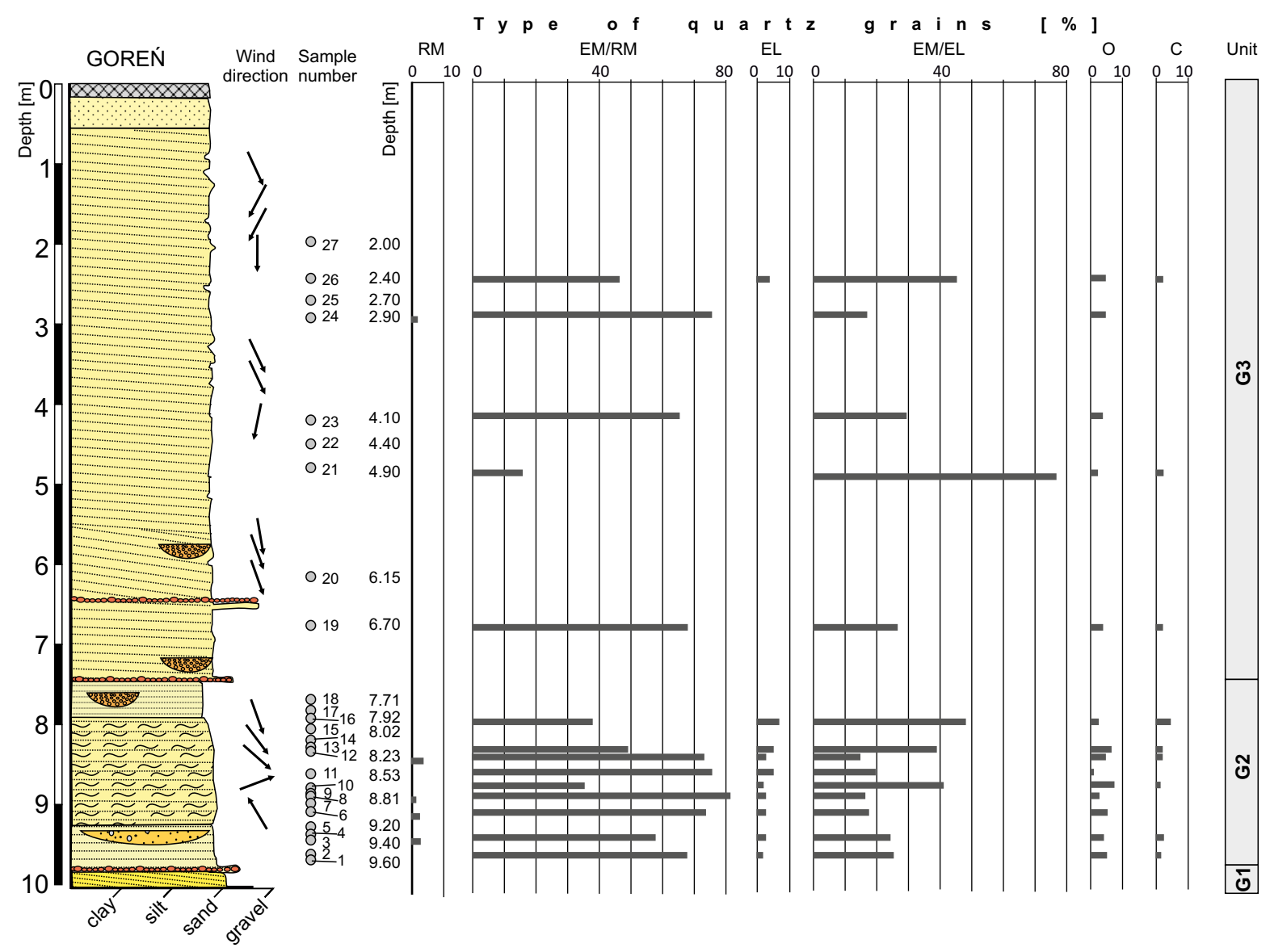

Figure 5. Results of frosting and rounding of quartz grains analysis performed on deposits from the Goreń Duży profile, following the modified method of Cailleux (1942) (Mycielska-Dowgiałło \& Woronko, 1998).

\section{Discussion}

\subsection{Reconstruction of depositional environments}

Three units of mineral sediments (G1-G3) distinguished at the site of Goreń Duży (Fig. 2) represent the main morphogenic stages of the Płock Basin development after the last ice-sheet retreat.

Unit G1 (Fig. 2) is associated with a midriverbed, being developed as prograding transverse bars and deposition on a slip face (distal slope) of the dune (Miall, 1996; Zieliński, 2014). These forms are characteristic structural elements of braided channels (Zieliński, 2014) which could be associated with the meltwater outflow from beneath the melting ice-sheet, or with the river water outflow located in the Płock Basin. The uppermost sediment layer of this unit is eroded, being manifested in a thin layer of very poorly rounded clasts of the gravel fraction (Fig. 2).

Unit G2 represents a gradual transition from the fluvial to the aeolian environment. Structural analysis of sediments of this unit proves that the deposition occurred in two different environments: 1) aeolian and 2) fluvial. Lithofacies Sh was associated with shallow and relatively intense flows within the upper plane bed conditions, whereas lithofacies St was deposited within small channelled subcritical flows (Zieliński, 2014). The bottom layer of gravel can be interpreted as lag deposits or deflation pavement, which indicates prolonged 
exposure to the wind action (Seppälä, 2003; Antczak-Górka, 2005; Woronko et al., 2015), whereas the middle part of the G2 unit, developed in the form of the Sh->SFw rhythmite the alternating silty sands with wavy lamination $(\mathrm{SFw})$ and horizontally stratified sands (Sh), originated as a result of aeolian accumulation (Hunter, 1977; Zieliński \& Issmer, 2008). Lithofacies Sh was deposited in the presence of strong winds, with ripple marks being replaced by a flat depositional surface (Goździk, 1998). Lithofacies SFw was probably deposited on a wet surface at much lower wind velocity (Kasse, 2002; Zieliński et al., 2016). Such sedimentary features are characteristic of fluvio-aeolian deposits, described at many locations in Europe (Kasse et al., 2007; Woronko et al., 2015; Zieliński et al., 2015, 2016). At the same time, the characteristics of G2 unit sediments indicate that the climate became drier, which directly resulted in the reduction of flows in the Płock Basin and in turn increased the activity of aeolian processes (Woronko et al., 2015; Zieliński et al., 2016). Their presence at Płock Basin indicate that wind is the main factor shaping exposed surfaces in vegetationfree areas, and coeval aeolian transport supplied the material to the fluvial environment (Goździk, 2007; Zieliński et al., 2015, 2016; Woronko et al., 2015). This activity is confirmed by the high proportion of sand grains of aeolian origin in the sediments of unit G2 (EM/RM) (Fig. 5). Moisture conditions during deposition varied, both on the dry and/or the humid substrate (Fig. 2). Negative values of skewness $\left(\mathrm{Sk}_{\mathrm{I}}\right)$ coarse along with the increased diameter of grains, and in particular the presence of medium and coarse-grained sands (Fig. 5) all indicate the dominance of deflation processes (wind erosion) with an increased in wind velocity. On the other hand, positive values of skewness $\left(\mathrm{Sk}_{\mathrm{r}}\right)$ of sediments along with the smaller average diameter of grains $(\mathrm{Mz})$ and the increased content of silt particles in the sediments indicate that this accumulation occurred at much lower wind velocities. The presence of several levels of small scale involutions/load cast up to $0.2 \mathrm{~m}$ and usually $2-5 \mathrm{~cm}$ in G2 unit sediments indicates interruptions in sedimentation and the presence of a humid sediment surface layer in the Płock Basin, which is reflected in the high content of silt particles (Fig. 4) (Pye \& Tsoar, 2009). The smallscale involutions documented in the profile (Fig. 2a) were formed under conditions of deep seasonal frost rather than during permafrost aggradation (Kasse, 2002; Zieliński et al., 2016). This indicates the mean annual average temperature (MAAT) was probably about -1 or $-2^{\circ} \mathrm{C}$ (Vandenberghe $\&$ Pissart, 1993).

Sediments of the G3 unit represent aeolian deposits that were deposited on the windward slope of the southern arm of a longitudinal dune. Sl stratification is a result of accretion (Hunter, 1977). Single channel structures occurring in the bottom layer of the G3 unit, filled with gravelly sand of massive structure (SGe) or cross-bedded (Sp) fill seems to suggest that those features are small deflation troughs. Several reactivation surfaces are present in the vertical profile of the dune being erosional surfaces characterised by a change of laminae inclination angle or an increase in coarsegrained layers (Fig. 2 c). They reflect the change in the wind direction. The fraction of $0.1-0.250 \mathrm{~mm}$ is the main fraction with very small variation of grain size indices $(\mathrm{Mz}$, sorting) with positive skewness $\left(\mathrm{Sk}_{\mathrm{I}}\right)$ throughout the whole unit (Fig. 4). This indicates relatively stable aerodynamic conditions, with only incidental dominance of deflation over accumulation.

\subsection{Intensity of aeolian processes}

Sand and gravel sediments of Płock Basin River and ice-marginal valley terraces were the source material for aeolian processes (Urbaniak-Biernacka, 1976). EM/RM grains dominate in the G2 and G3 units. RM grains were not registered in the dune sediments of the G3 unit and only a small percentage was found in the fluvio-aeolian unit (G2) (Fig. 5). This indicates that the abrasion period was relatively short and/or the transport distance in this aeolian environment was short too (MycielskaDowgiałło, 1993; Kalińska-Nartiša et al., 2015). 
By comparison, the RM content in extraglacial zone dune sediments of the Polish sector of the European Sand Belt is up to $50 \%$ (Cailleux, 1942; Goździk, 2007; Woronko et al., 2015; Zieliński et al., 2015, 2016). The presence of EM/EL and EL grains, whose surface is affected by fluvial environment processes, indicates a continuous supply of material for aeolian transport ultimately forming, in example, fluvial, glaciofluvial or glacio-lacustrine deposits. Furthermore, the lack of aeolian environment processing on EM/EL and EL grains along with a varying contribution of $\mathrm{EM} / \mathrm{RM}$ grains in the vertical profile, indicate that in this depositional environment fast aggradation dominated over long-range transport. In addition, aeolian processes in the G3 unit sediments led to the elimination of the finest $(<0.05 \mathrm{~mm})$ and coarse $(>0.315 \mathrm{~mm})$ fractions recorded in substrate sediments (Fig. 4). At the same time, the variability of types of grain indices in the vertical profile suggests increased desiccation of the surface sediment layer during the process of dune accumulation, which can be related to progressive permafrost degradation. Such conditions resulted in an increased infiltration rate with a commensurate drying of the uppermost layer of sediments, further resulting in increased deflation with the delivery of large amounts of material to the aeolian environment. The small percentage of organic matter in these dune sediments indicates that the soils were poorly developed, and their particles were likely to be removed by wind action. Also noteworthy is that no RM-type grains were found in dune sediments (unit G3). This is contrast to fluvio-aeolian unit G2, which underlies the sediments of the unit G3. This phenomenon may indicate that during the period of dune accumulation in this area, the wind-entrained material was supplied from outside the Płock Basin. Woronko et al. (2015) arrived at similar conclusions.

\subsection{The age of aeolian deposits}

Apart from the dune in Liszyno near Płock, the Płock Basin lacks absolute dating of the activation of aeolian processes. ${ }^{14} \mathrm{C}$ dating of the dune in Liszyno revealed that Allerød fossil soil separates two aeolian series a lower one from the Older Dryas and an upper one dated to the Younger Dryas (Kamińska et al., 1986). OSL dating of the aeolian unit base presented in Goreń Duży $(13.06 \pm 0.76 \mathrm{ka}$ and $13.54 \pm 0.84 \mathrm{ka}$; Fig. 3; Table 2) indicates that the initial fluvio-aeolian formation should be referred as an Older Dryas deposit. The obtained OSL dates correspond with the deposition of cover sand overlying the Finow soil (about $13.5 \mathrm{ka}$ ) in Mecklenburg, NE Germany (Küster \& Preusser, 2009), or the first stage of the development of aeolian processes in NE Estonia dated at $13.3 \pm 1.2 \mathrm{ka}$ (KalińskaNartiŝa et al., 2015). Moreover, dating results can be related to chronostratigraphic correlations based on the analysis of laminated sediments of Lake Meerfelder and Lake Gościąż (Litt et al., 2001, Ralska-Jasiewiczowa et al., 1998). The Older Dryas is commonly associated with the intensive development of aeolian processes within the European Sand Belt in Poland, Germany, and in the Baltic countries (Manikowska 1985, Nowaczyk 1986, Kasse, 1997, 2002; Zeeberg, 1998; Kasse et al., 2003, Hilgers, 2007; Kaiser et al., 2009, Kalińska-Nartiŝa et al., 2015, 2016; Zieliński et al., 2016). The overlying fluvio-aeolian sediments of unit G2 and dune sediments of unit G2 are associated with the reactivation of aeolian processes in the Younger Dryas. The beginning of reactivation in this period is marked by the erosional boundary between the units G2 and G3. The Younger Dryas is accepted as the primary dune-forming period in the Torun Basin, which is adjacent to the Płock Basin (Andrzejewski \& Weckwerth, 2010, Jankowski 2012; Zieliński et. al., 2016). The presence of unit G3 aeolian process reactivation surfaces results in dune formation by wind from a different direction.

A salient point is the relationship of these dunes to the deep subglacial channels that were preserved for a long time in association with dead ice blocks (Błaszkiewicz, 2011; Błaszkiewicz et. al., 2015), which at the same time becomes a useful element in the pursuit of aeolian process age determination. 
The main phase of buried, dead-ice melting in the Płock Basin, took place during the Allerød (RalskaJasiewiczowa et. al., 1998). In the study area, large parabolic dunes are often "intersected" by subglacial channels. The morphological relationship between the dune forms and the subglacial channels strongly suggests a pre-Allerød (pre-melting phase) age for the aeolian processes that took place within the Płock Basin. Our research fully confirms this thesis, while taking into consideration a subsequent aeolian transformation in the Younger Dryas.

\section{Conclusions}

Sediments of the Goreń Duży profile represent three environments: 1) fluvial unit G1, 2) fluvioaeolian unit G2 and 3) aeolian unit G3. Each recorded environmental changes in an area that was released from the ice cover around $18.4 \mathrm{ka}$. The accumulation of the fluvio-aeolian unit was supported through aeolian and fluvial processes. The accumulation of this unit coincides with the Older Dryas. The accumulation of unit G3 occurred during the Younger Dryas. The homogeneous nature of grain size composition throughout the dune profile indicates homoge-

\section{References}

Adamiec, G. \& Aitken, M. J. 1998. Dose-rate conversion factors: update. Ancient TL 16, 37-50.

Aitken, M. J., 1998. An Introduction to Optical Dating: The Dating of Quaternary Sediments by the Use of PhotonSimulated Luminescence. Oxford University Press, Oxford, $276 \mathrm{p}$.

Andrzejewski, L. \& Weckwert, P., 2010. Dunes of the Torun Basin against paleogeographical conditions of the Late Glacial and Holocene. Ecological Questions 12, Special Issue, 9-15. https://doi.org/10.2478/v10090-010-0001-4.

Antczak-Górka, B., 2005. Głazy rzeźbione przez wiatr jako wskaźnik różnowiekowych stref peryglacjalnych ostatniego zlodowacenia w Polsce Zachodniej. Wydawnictwo Naukowe UAM, 212 p. (in Polish).

Bateman, M.D., 2008. Luminescence dating of periglacial sediments and structures. Boreas 37, 574-588. https://doi.org/10.1111/j.1502-3885.2008.00050.x neous wind conditions throughout this sediment accumulation. Aeolian processes during the accumulation of the fluvio-aeolian unit (G2) and dune unit (G3) were short-lived, accompanied by a large supply of the wind-entrainable material, which was conducive to the deposition rather than the deflation (wind erosion). The relationship of dunes to subglacial channels that developed after the melting of dead-ice blocks confirms a preAllerød origin of aeolian processes.

\section{Acknowledgements}

The authors are grateful to anonymous reviewers for their insightful and helpful comments and suggestions that have greatly helped to improve the first version of the manuscript. This study is a contribution to the scientific project financed by the National Fund for Environmental Protection and Water Management as part of the Polish Geological Survey and the National Science Centre in Poland (project no. UMO-2015/19/B/ ST10/03039). Mark Demitroff (Stockton University, USA) is thanked for English proof-reading that significantly improved our manuscript. We thank both reviewers for valuable suggestions.

Blott, S.J. \& Pye, K., 2001. Gradistat: a grain size distribution and statistics package for the analysis of unconsolidated sediments. Earth Surface Processes and Modern Environments 26, 1237-1248. https://doi.org/10.1002/esp.261

Błaszkiewicz, M., 2011, Timing of the final disappearance of permafrost in the Central European Lowland as reconstructed from the evolution of lakes in N Poland. Geological Quarterly 55, 361-374.

Błaszkiewicz, M, Piotrowski, J.A., Brauer, A., Gieryszewski, P., Kordowski, J., Kramkowski, M., Lamparski, P., Lorenz, S., Noryśkiewicz, A.M., Ott, F., Słowiński, M. \& Tyszkowski, S., 2015. Climatic and morphological controls on diachronous postglacial lake and river valley evolution in the area of Last Glaciation, northern Poland. Quaternary Science Reviews 109, 13-27. https://doi.org/10.1016/j.quascirev.2014.11.023 
Cailleux, A., 1942. Les actiones éoliennes périglaciaires en Europe. Mémoires de la Société géologique de France 41, 1-176. (in French)

Dylikowa, A., 1967. Wydmy środkowopolskie i ich znaczenie dla stratygrafii schyłkowego plejstocenu. In: Galon R., Dylik J. (eds.), Czwartorzęd Polski, 353-371. (in Polish)

Dylikowa, A., 1968. Fazy rozwoju wydm w środkowej Polsce w schyłkowym plejstocenie. Folia Quaternaria 29, 119126. (in Polish)

Folk, R.L. \& Ward, W.C., 1957. Brazos River bar, a study in the significance of grain size parameters. Journal of Sedimentary Petrology 27, 3-26. https://:doi.org/10.1306/74D70646-2B21-11D7$8648000102 \mathrm{C} 1865 \mathrm{D}$

Galbraith, R.F., Roberts, R.G., Laslett, G.M., Yoshida, H. \& Olley, J.M., 1999. Optical dating of single and multiple grains of quartz from Jinminum Rock Shelter, Northern 12 Australia. Part I, experimental design and statistical models. Archaeometry 41, 1835-1857. https://doi.org/10.1111/j.1475-4754.1999.tb00987.x

Galon, R. \& Roszkówna, L., 1961. Extents of the Scandinavian glaciations and of their recession stages on the territory of Poland in the light of an analysis of marginal forms of inland ice. Przegląd Geograficzny 33, 347-364.

Goździk, J., 1998. Struktury sedymentacyjne w eolicznych piaskach pokrywowych w Polsce. In: MycielskaDowgiałło E. (eds.), Struktury sedymentacyjne i postsedymentacyjne w osadach czwartorzędowych i ich wartość interpretacyjna. WGiSR UW,167-191. (in Polish)

Goździk, J., 2007. The Vistulian aeolian succession in central Poland. Sedimentary Geology 193, 211-220. https://:doi.org/10.1016/j.sedgeo.2005.11.026

Hilgers, A., 2007. The chronology of Late Glacial and Holocene dune development in the northern Central European lowland reconstructed by optically stimulated luminescence (OSL) dating. Phd-Thesis. University of Cologne. 440 p.

Hunter, R.E., 1977. Basic types of stratification in small eolian dunes. Sedimentology 24, 361-387. https://doi.org/10.1111/j.1365-3091.1977.tb00128.x

Jankowski, M., 2012. Lateglacial soil paleocatena in inlanddune area of the Torun Basin, Northern Poland. Quaternary International 265, 116-125. https://doi.org/10.1016/j.quaint.2012.02.006

Kaiser, K., Hilgers, A., Schlaak, N., Jankowski, M., Kühn, P., Bussemer, S. \& Przegiętka, K., 2009. Palaeopedological marker horizons in northern central Europe: characteristics of Lateglacial Usselo and Finow soils. Boreas 38, 591-609. https://doi.org/10.1111/j.1502-3885.2008.00076.x

Kalińska-Nartiša, E., Nartišs, M., Thiel, Ch., Buylaert, J.P. \& Murray, A.S., 2015. Late-glacial to Holocene aeolian deposition in northeastern Europe e The timing of sedimentation at the Iisaku site (NE Estonia). Quaternary International 357, 70-81. https://doi.org/10.1016/j.quaint.2014.08.039
Kalińska-Nartiša, E., Thiel, Ch., Nartišs, M., Buylaert, J.P. \& Murray, A., 2016. The north-eastern aeolian 'European Sand Belt' as potential record of environmental changes: a case study from Eastern Latvia and Southern Estonia. Aeolian Research 22, 59-72. https://:doi.org/10.1016/j.aeolia.2016.06.002

Kamińska, R., Konecka-Betley, K. \& Mycielska-Dowgiałło, E., 1986. The Liszyno dune in the Vistula Valley (east of Płock). Biuletyn Peryglacjalny 31, 141-162. (in Polish)

Kasse, C., 1997. Cold-Climate Aeolian Sand-Sheet Formation in North-Western Europe (c. $14 \pm 12.4 \mathrm{ka}$ ); a Response to Permafrost Degradation and Increased Aridity. Permafrost and Periglacial Processes, 8, 295-311. h t t p : / / doi.org/ 10.1002 / ( S I C I) 1099 1530(199709)8:3<295::AID-PPP256>3.0.CO;2-0

Kasse, C., 2002. Sandy aeolian deposits and their relation to climate during the Last Glacial Maximum and Lateglacial in northwest and central Europe. Progress in Physical Geography 26, 507-532. https://:doi.org/10.1191/0309133302pp350ra

Kasse, C., Vandenberghe, J., Van Huissteden, J., Bohncke, S.J.P. \& Bos, J.A.A., 2003. Sensitivity of Weichselian fluvial systems to climate change (Nochten mine, eastern Germany). Quaternary Science Reviews 22, 2141-2156. https://:doi.org/10.1016/S0277-3791(03)00146-X

Kasse, C., Vandenberghe, D., De Corte, F. \& Van den Haute, P., 2007. Late Weichselian fluvio-aeolian sands and coversands of the type locality Grubbenvorst (southern Netherlands): sedimentary environments, climate record and age. Journal of Quaternary Science 22, 695-708. https://:doi.org/10.1002/jqs. 1087

Koster, E.A., 1988. Ancient and modern cold-climate aeolian sand deposition: a review. Journal of Quaternary Science 3, 69-83. https://doi.org/10.1002/jqs.3390030109

Koster, E.A., 2005. Aeolian environments. In: Koster, E. A. (eds.) The Physical Geography of Western Europe. Oxford University Press, Oxford, pp. 139-159.

Kozarski, S., 1965. Zagadnienie drogi odpływu wód pradolinnych z zachodniej części Pradoliny NoteciWarty. Poznańskie Towarzystwo Przyjaciół Nauk, Prace Komisji Geograficzno-Geologicznej 5:1, 97 p. (in Polish)

Krumbein, W.C.,1941. Measurement and geological significance of shape and roundness of sedimentary particles. Journal of Sedimentary Petrology 11, 64-72. https://doi.org/10.1306/D42690F3-2B26-11D7$8648000102 \mathrm{C} 1865 \mathrm{D}$

Küster, M. \& Preusser, F., 2009. Late Glacial and Holocene aeolian sands and soil formation from the Pomeranian outwash plain (Mecklenburg, NE-Germany). Quaternary Science Journal 58, 156-163. https://:doi.org/10.3285/eg.58.2.04

Lencewicz, S.,1927. Dyluwium i morfologia środkowego Powiśla. Prace PIG 2(2), 66-226 (in Polish with French summary).

Litt, T., Brauer, A., Goslar, T., Lotter, A., Merkt, J. \& RalskaJasiewiczowa, M., 2001. Correlation of Large-scale 
Climate Events during the Lateglacial and Early Holocene as Inferred from the Study of Annually Laminated Lake Sediments. Terra Nostra 2001/3, 26-32. https://:doi.org/10.1016/j.quaint.2015.08.089

Manikowska, B., 1985. O glebach kopalnych, stratygrafii i litologii wydm Polski środkowej. Acta Geographica Lodziensia 52, 1-137. (in Polish)

Miall, A.D., 1996. The Geology of Fluvial Deposits. Sedimentary Facies, Basin Analysis, and Petroleum Geology. Springer, Berlin-Heidelberg-New York, 582 p.

Moska, P., 2017. Datowanie luminescencyjne metoda OSL 111 próbek osadów czwartorzędowych. Raport, NAG Polish Geological Insitute-National Reaearch Institute, Warsaw. (in Polish)

Murray, A.S. \& Roberts, R.G., 1998. Measurement of the equivalent dose in quartz using a regenerative-dose singlealiquot protocol. Radiation Measurements 29, 503-515. https://doi.org/10.1016/S1350-4487(98)00044-4

Mycielska-Dowgiałło, E., 1993. Estimates of Late Glacial and Holocene aeolian activity in Belgium, Poland and Sweden. Boreas 22, 165-170. https://doi.10.1111/j.1502-3885.1993.tb00177.x

Mycielska-Dowgiałło, E., 2001. Wpływ warunków klimatycznych na cechy strukturalne i tekstualne osadów mineralnych. In: Karczewski A. \& Zwoliński Z. (eds.), Funkcjonowanie geosystemów w zróżnicowanych warunkach morfoklimatycznych - monitoring, ochrona, edukacja. Poznań, pp. 377-394. (in Polish)

Mycielska-Dowgiałło, E. \& Woronko, B., 1998. Analiza obtoczenia i zmatowienia powierzchni ziarn kwarcowych frakcji piaszczystej i jej wartość interpretacyjna. Przegląd Geologiczny 46, 1275-1281 (in Polish with English summary).

Mycielska-Dowgiałło, E. \& Woronko, B., 2004. The degree of aeolization of Quaternary deposits in Poland as a tool for stratigraphic interpretation. Sedimentary Geology 168, 149-163.

https://doi. 10.1016/j.sedgeo.2003.12.006

Nowaczyk, B., 1986. Wiek wydm w Polsce, ich cechy granulometryczne i strukturalne, a schemat cyrkulacji atmosferycznej w późnym vistulianie i holocenie. UAM ser. geogr. 26, Poznań. (in Polish)

Pisarska-Jamroży, M., 2015. Factors controlling sedimentation in the Torun-Eberswalde ice-marginal valley during the Pomeranian phase of Weichselian glaciation: an overview. Geologos 21, 1-29. https://:doi.org/10.1515/logos-2015-0001

Punkari, M., 1997. Glacial and glaciofuvial deposits in the interlobate areas of the Scandinavian Ice Sheet. Quaternary Science Reviews 16, 741-753. https://doi.org/10.1016/S0277-3791(97)00020-6

Pye, K. \& Tsoar, H., 2009. Aeolin sand and sand dunes. London, Springer Science \& Business Media, 458 p. https://doi.org/10.1007/978-3-540-85910-9

Ralska-Jasiewiczowa, M., Goslar T., Madeyska, T. \& Starkel, L. (eds.), 1998. Lake Gościąż, central Poland. A
Monographic Study Part 1. Szafer Institute of Botany, Polish Academy of Sciences, Kraków, 340 p. (in Polish)

Roman, M., 2010, Rekonstrukcja lobu płockiego w czasie ostatniego zlodowacenia. Acta Geographica Lodziensia 96, 171 p. (in Polish)

Rychel, J., Woronko, B., Karasiewicz, M.T. \& Błaszkiewicz, M., 2015. Stanowisko 4 - Goreń: wydma w Goreniu Dużym - przykład formy eolicznej w Kotlinie Płockiej. W: Plejstocen Kotliny Płockiej oraz postglacjalna transformacja jej rzeźby: XXII Konferencja naukowoszkoleniowa Stratygrafia plejstocenu Polski, Gołaszewo, 31.08-4.09.2015 r. (eds.) Jarosław Kordowski Uniwersytet Warszawski, Warszawa, pp. 135-138. (in Polish)

Seppälä, M., 2003. Wind as a geomorphic agent in cold climates. Cambridge University Press, Cambridge, 358 p.

Skompski, S., 1969. Stratygrafia osadów czwartorzędowych wschodniej części Kotliny Płockiej, Z badań czwartorzędu w Polsce, 12, Biul. PIG, 220 p. (in Polish)

Tylman, K., Rinterknecht, V. \& Woźniak, P.P., 2017. ${ }^{10}$ Be age of the Local Last Glacial Maximum in the southern fringe of the Scandinavian Ice Sheet. In: Sarala, P. \& Johansson, P. (eds.), INQUA Peribaltic Working Group Meeting and Excursion 2017, 20 - 25 August 2017. Geological Survey of Finland, p. 163.

Urbaniak, U., 1962. Struktura wydmy w Goreniu Dużym. Przegląd Geograficzny 34, 119-128. (in Polish)

Urbaniak, U., 1967. Wydmy Kotliny Płockiej. Prace Geograficzne 61, IGiPZ PAN, Wydawnictwa Geologiczne Warszawa, p 79. (in Polish)

Urbaniak-Biernacka, U., 1976. Badania wydm środkowej Polski z wykorzystaniem metod statystycznych. Wyd. Politechniki Warsz. Warszawa. Prace Naukowe, Geodezja 17, 1-204. (in Polish)

Vandenberghe, J. \& Pissart, A., 1993. Permafrost changes in Europe during the last glacial. Permafrost and Periglacial Processes 4, 121-135. https://:doi.org/10.1002/ppp.3430040205

van Huissteden, Ko (J.), Schwan, J.C.G. \& Bateman, M.D., 2001. Environmental conditions and paleowind directions at the end of the Weichselian Late Pleniglacial recorded in aeolian sediments and geomorphology (Twente, Eastern Netherlands). Geologie en Mijnbouw $80: 2,1-18$

Woronko, B., Zieliński, P. \& Sokołowski, R.J., 2015. Climate evolution during the Pleniglacial and Late Glacial as recorded in quartz grain morphoscopy of fluvial to aeolian successions of the European Sand Belt. Geologos 21, 89-103. https://:doi.org/10.1515/logos-2015-0005

Wysota, W. \& Molewski, P., 2011. Chronologia i zasięgi nasunięć lądolodu na obszarze lobu Wisły podczas stadiału głównego ostatniego zlodowacenia (Chronology and extents of ice sheet advances in the Vistula lobe area during the Main Stage of the Last Glaciation). Przegląd Geologiczny 59, 214-225 (in Polish with English summary). 
Wysota, W., Molewski, P. \& Sokołowski, R.J., 2009. Record of the Vistula Ice Lobe advances in the Late Weichselian glacial sequence in north-central Poland. Quaternary International 207, Special Issue, 26-41.

https://:doi.org/10.1016/j.quaint.2008.12.015

Zeeberg, J., 1998. The European sand belt in eastern Europe e and comparison of Late Glacial dune orientation with GCM simulation results. Boreas 27, 127-139. https://doi.org/10.1111/j.1502-3885.1998.tb00873.x

Zieliński, T., 2014. Sedymentologia. Osady rzek i jezior. Wyd. Naukowe UAM, 1-594. (in Polish)

Zieliński, P. \& Issmer, K., 2008. Propozycja kodu genetycznego osadów środowiska eolicznego Przegląd Geologiczny 56, 67-72 (in Polish with English summary).

Zieliński, T. \& Pisarska-Jamroży, M., 2012. Jakie cechy litologiczne osadów warto kodować, a jakie nie? Przegląd Geologiczny 60:7, 387-397 (in Polish with English summary).
Zieliński, P., Sokołowski, R., Fedorowicz, S. \& Jankowski, M. 2011. Stratigraphic position of fluvial and aeolian deposits in the Żabinko site (W Poland) based on TL dating. Geochronometria 38, 64-71.

https://doi. 10.2478/s13386-011-0005-x

Zieliński P., Sokołowski R.J., Woronko B., Jankowski M., Fedorowicz S., Zaleski I., Molodkov A. \& Weckwerth P., 2015. The depositional conditions of the fluvio-aeolian succession during the last climate minimum based on the examples from Poland and NW Ukraine. Quaternary International 386, 30-41.

https://doi.org/10.1016/j.quaint.2014.08.013

Zieliński, P., Sokołowski, R.J., Woronko, B., Jankowski, M., Fedorowicz, S. \& Standzikowski, K., 2016. Sandy deposition in a small dry valley in the periglacial zone of the Last Glacial Maximum: A case study from the Józefów site, SE Poland. Quaternary International 399, 58-71. https://doi.org/10.1016/j.quaint.2015.08.089 